\title{
Social sciences have so much more to bring to climate studies in forest research: a French case study
}

\author{
Timothée Fouqueray $^{1}$ (D) Nathalie Frascaria-Lacoste ${ }^{1}$
}

Received: 10 June 2020 / Accepted: 23 July 2020 / Published online: 17 August 2020

(C) INRAE and Springer-Verlag France SAS, part of Springer Nature 2020

\begin{abstract}
- Key message Faced with wicked problems such as climate change, managers of complex forest social-ecological systems require more than experimental sciences alone. Yet, mitigation and adaptation studies underuse social sciences in forest research, as shown here with the French case study. Therefore, we stress the value of social sciences for forest researchers, and extend this reflection to research funding bodies, forest authorities, foresters, and society at large. We identify training and publications as the main levers for more holistic forest research, and posit that with short-, mid-, and long-term changes, social sciences can complement (not replace) experimental sciences in climate studies led by forest researchers.
\end{abstract}

Keywords Climate change $\cdot$ Forest sciences $\cdot$ Social sciences $\cdot$ Interdisciplinarity $\cdot$ Research orientation $\cdot$ Funding

\section{Introduction}

Climate change threatens the current living conditions of most living creatures, including humans (Diaz et al. 2019). Research efforts have intensified on the topic (Haunschild et al. 2016), highlighting how human-induced climate upheaval, along with global changes such as habitat loss and degradation, alters the trajectories of ecosystems worldwide. The mitigation of carbon emissions and adaptation to the many consequences of climate change (hereinafter "adaptation") are now acknowledged as complementary ways to address this issue.

Climate studies call on a wide array of disciplinary approaches to tackle the intrinsic complexity of the issues raised by climate

\section{Handling Editor: Erwin Dreyer}

Contribution of the co-authors TF conceived, designed, and wrote the paper and figures; NF made additional contributions and edited the manuscript.

Electronic supplementary material The online version of this article (https://doi.org/10.1007/s13595-020-00989-3) contains supplementary material, which is available to authorized users.

Timothée Fouqueray

timothee.fouqueray@universite-paris-saclay.fr

1 Ecologie, Systématique, Evolution, AgroParisTech, CNRS, University Paris-Sud, Université Paris-Saclay, 91405 Orsay, France change. The factors influencing successful mitigation and adaptation range from individual adaptive behaviors (Luthe and Wyss 2015) and collective organization (Jacobs et al. 2015) to economic strategies (e.g., Brèteau-Amores et al. 2019), to name but a few. Regarding adaptation, disciplinary insights from the social sciences (such as psychology, sociology, human geography, but also economics; for a detailed understanding of the social sciences, see Moon and Blackman 2014) are necessary to produce general knowledge of a "science of adaptation" (Swart et al. 2014), which currently remains focused on experimental sciences. At the same time, many problem-solving authors recognize the complementary need for an integrative and interdisciplinary "science for adaptation" in order to deal with issues such as the management of uncertainty in forest ecosystems (Keenan 2015). Interdisciplinary climate research integrates different disciplinary insights into a single framework, whether at the researcher, project/article, or research program level (Shaman et al. 2013).

Climate studies in forest research are a paragon of the need to include disciplinary and interdisciplinary insights from the social sciences into problem-solving projects. On the one hand, climate change is a wicked problem with no optimal solution that is easily replicable across time, space, or decision-making levels (Sun and Yang 2016). On the other hand, forestry - the art of creating, restoring, or using forested areas in order to conserve them and benefit from their goods and services - is precious in the fight against climate change: it can enhance forests' capacity to act as carbon sinks and help them adapt to climate change 
(Edenhofer and IPCC 2014). Still, research on the management of complex forest social-ecological systems is entangled in multilayered social, economic, and ecological variables. Hence, climate studies in forest research fully correspond to "post-normal science," where "facts are uncertain, values in dispute, stakes high, and decisions urgent" and where plural perspectives are justified (Funtowicz and Ravetz 1994) - from the disciplinary and interdisciplinary social sciences, for instance.

Paradoxically, despite their importance in climate studies, social sciences are underused in forest research in comparison with experimental sciences. There is a sizeable literature on the contribution of managed and unmanaged forests to the mitigation of and adaptation to climate change (Lindner et al. 2010). Publications have reviewed the "science of adaptation," such as the physiological and evolutive impacts of climate change on trees (Aitken et al. 2008), or the evolutive processes favoring adaptation (Bussotti et al. 2015). Publications in the "science for adaptation" discuss management practices in favor of adaptation (Keenan 2015; Marchi et al. 2018) or report their implementation in the field (Nelson et al. 2016; Fouqueray et al. 2020). Further research on genetics, physiology, ecology, and climate studies is required to improve our knowledge of forest functioning under a changing climate. However, we posit that there is scope for complementary approaches to the experimental sciences, which will be able to (partly) handle the inevitable uncertainties (Spittlehouse and Stewart 2004; Dessai et al. 2009). In our opinion, it would be beneficial for the forest sciences as well as sound forest policies to support projects based on social sciences. For instance, social sciences may be able to identify levers for biomass production based on economic organizations that are more resilient to climate impacts (Brunette et al. 2017). However, in our experience, more than two decades since the call for "Integrating Social Sciences into Forest Ecosystem Management Research" (Marcin 1995), social sciences are still overlooked in climate studies in forest research. With the notable exception of the Canadian community forestry research (Klenk et al. 2010; Bullock and Lawler 2015), this absence of social sciences is common for the broader context of climate and environmental studies (Machlis 1992; Weaver et al. 2014; Barnes and Dove 2015; Wong-Parodi et al. 2016).

In this opinion paper, although we plea for a genuine opening of climate studies in forest research to social sciences, we especially describe why, in our view, this would benefit all forest stakeholders. To this end, we focus on the value of increasing the contribution of social sciences for five groups of stakeholders, namely researchers, research funders, forest authorities, foresters (i.e., forest managers and/or owners), and society at large. We begin by presenting a national case study, namely two decades of public funding in French climate and forest research. For each of the abovementioned forest stakeholders, we use the French case to review their capacities and opportunities to include more social sciences in this research field. We conclude with propositions on the role of researchers in the holistic inclusion of social sciences in climate studies in forest research.

\section{Two decades of funding of climate studies in French forest research}

We chose France as a case study, because it has one of Europe's largest areas of forests $\left(165,000 \mathrm{~km}^{2}\right)$ on which numerous jobs and forested habitats depend (MAAF 2017). Many French policies relate to forestry and include specific mentions of climate change: the National Plan for the Adaptation to Climate Change (ONERC 2017), the National Mitigation Strategy (MTES 2020), the National Strategy for Biomass Mobilization (MTES 2018), the National Strategy for Biodiversity (Ministère de l'écologie, du Développement durable et de l'énergie 2012), and so on.

\subsection{Tracking the integration of social sciences through project funding}

Data collection was inspired by García and Sanz-Menéndez (2005): we relied on public project funding as a proxy for the research effort of including the social sciences in French climate studies in forest research. Public project funding has become the prevailing means of state bodies to fund research (Geuna 2001). Applicants write proposals describing the research activities to be performed with a limited budget and time, their compliance with the stated scope, and their correspondence to the expected outcomes (Meyer and Molyneux-Hodgson 2010). In France, calls for proposals on climate change or forests originate from the ministries responsible for the forests (https://agriculture.gouv.fr) , research (https://www.enseignementsup-recherche.gouv.fr), and the environment (https://www.ecologique-solidaire.gouv.fr) , from the Agency for the Environment and Management of Energy (ADEME, https://www.ademe.fr/), and from the National Agency for Research (ANR, https://anr.fr/). In addition, networks of forest professionals (researchers with managers) also issue calls for proposals, in particular the public interest group "Forest Ecosystems" (ECOFOR, http://www.gipecofor.org/), the scientific interest group "Climate, Environment, and Society" (http://www.gisclimat.fr/), the transdisciplinary public network for the "Adaptation of Forests to Climate Change" (AFORCE, https://www.reseau-aforce.fr/), and the Programs for and on Regional Development (PSDR, https:// www.psdr.fr/).

In our view, whenever feasible, this tracking of project funding better reflects the effort invested by research stakeholders compared with bibliometric approaches, which can be biased by the academic popularity of a topic. Moreover, using bibliometric tools to estimate the inclusion of social sciences in climate studies in forest research funding would have been a challenging task, because of the divergent publication patterns in the social and experimental sciences. Therefore, we decided not to build on the proportion of climate studies in forest research publications that include the social sciences. Although unavailable data hindered further analyses (e.g., proposals rejected by selection committees, content of the 
calls for proposals), we considered our approach to be justified by similar methodologies reported in the literature (Dunningham et al. 2018; Fankhauser et al. 2019).

Our approach consisted of two steps. First, we compiled a list of French research laboratories hosted in one of the following research institutes that is potentially related to forests or climate: National Center for Scientific Research (CNRS), National Research Institute for Agriculture, Food and Environment (INRAE), National Research Institute of Science and Technology for Environment and Agriculture (IRSTEA), National Museum of Natural History (MNHN), National Institute of Geographic and Forest Information (IGN), and Forestry Development Institute (IDF). We used the search engines of each institute to separately look for one of the following keywords: "climat" (French for "climate"), "climatique" ("climatic"), and "forêt" and "forest"" ("forest" as a noun and an adjective). We excluded from our analysis research focusing on agroforestry and hedgerows. Overall, we identified 32 research laboratories. Second, we used the website search engines of the 32 laboratories to list their funded projects using the keywords of step 1. As the basic unit of observation, we retained projects specified with a relevant name, website, and description. In a spreadsheet, we recorded the project name, start year, end year, and description (e.g., using the "overview," "objectives," or "work packages" sections) with data extracted from the websites of each compiled research project.

We crosschecked the ability of the two-step methodology to identify relevant projects by replicating it using the search engines of the research funding bodies. Data collection took place in April 2018. We obtained a list of 163 research projects funded via the public calls for proposals between 1997 and 2017 (hereafter referred as "Table 1 continued online," data set available online (Fouqueray 2020)).

\subsection{Classification of climate studies in forest research}

We made a threefold classification by thoroughly investigating the online content of the 163 research projects.

First, we looked at the integration of social sciences. We considered that they were part of a project if its description reported the inclusion of geographers, sociologists, or economists, and/or the use of questionnaires, surveys, interviews, economic calculations, econometrics, or serious games.

Second, we investigated if the research project, whether or not it dealt with adaptation, accounted for mitigation in at least one work package.

Third, we classified the projects using their two key topics, or "main focuses," to cover the variety of components and linkages between forest social-ecological systems and climate change. The objective was to grasp the extent to which the projects' main focuses covered topics specific to the social sciences. Each project was consequently assigned two of the following main focuses: "Climate change-related risk,"
"Forest compartment," "Forest ecosystem," "Ecosystem goods and services," or "Forester." Illustrations of this categorization are provided in Table 1.

To increase the granularity of our analysis, we further subdivided each main focus into categories. For instance, the "Forester" main focus was further refined as either "Owners" or "Managers." The full subdivision is presented in Fig. 1.

\subsection{A brief overview of French climate studies in forest research}

Overall, only 25 out of 163 projects explicitly mention social or economic tools, 16 of which were funded after 2012 (Fig. 2, Table 1 continued online). The predominance of projects based on experimental sciences (ecology, climatology, pedology, forestry, physiology, or genetics) over projects based on social sciences was consistent over time (Fig. 2).

Most projects combining productive ecosystem services (e.g., biomass production) and to some extent non-productive ecosystem services (e.g., ecological conservation) tend to overlook social sciences, as found by Dobbertin and Nobis (2010). The vast majority of projects tackle adaptation to climate change from the perspective of biological mechanisms through assisted migration, species introduction, species mixes, or soil preparation. Only $15 \%$ of projects explore the direct and indirect consequences of climate change on forests using an economic or social approach such as the NEWFOREX project, which aims to assess forest externalities such as carbon sequestration (Table 1). The limited number of projects involving social sciences (only 7 projects with a main focus on foresters) and their recent emergence in the field of forestry underline the fact that social drivers are not given full consideration in forestry research.

\section{Climate studies in forest research: the beneficial effects of including more social sciences for forest stakeholders}

Given that research governance involves a variety of embedded institutions, agencies, and funding rationales (Lepori and Reale 2019), we do not seek to be exhaustive but instead concentrate on researchers, funding bodies, national authorities, forest managers, and society at large.

\subsection{Social sciences: an opportunity for forest researchers doing climate studies}

Forest researchers leading climate studies can benefit in different ways from a better consideration of social sciences in their academic activities.

Opening climate studies in forest research to social sciences can improve the quality of knowledge produced by seeking an interdisciplinary definition of best practices in transparent 


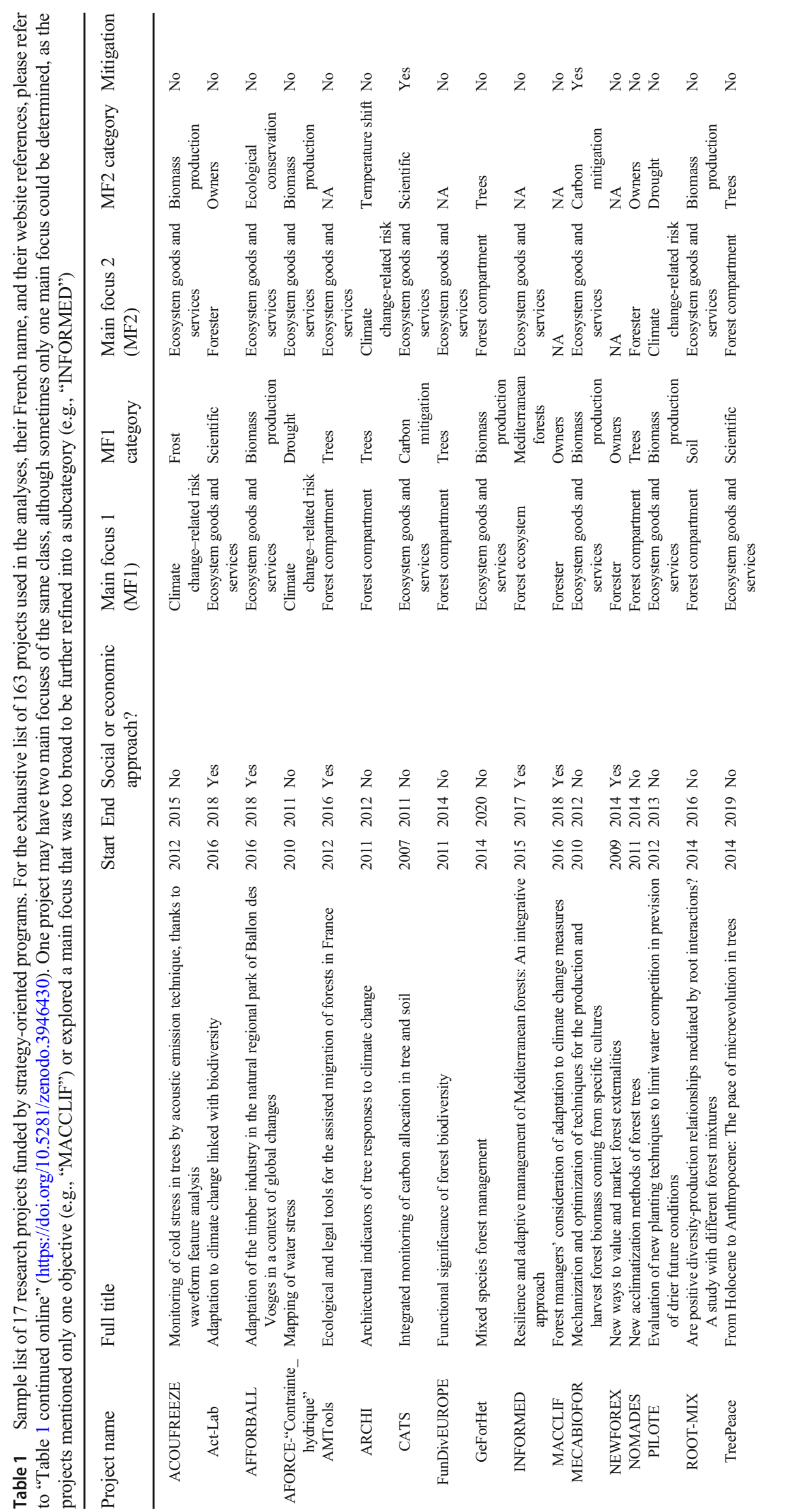


Fig. 1 Main focuses of research projects funded by strategyoriented programs and their categorization. Inner circle: distribution of the two main focuses of 163 projects (as 17 projects only had one main focus, the total number of main focuses in the inner circle was less than 326). Outer circle: details of the main focus categories; three categories of the main focus class

"Ecosystem goods and services" were not attributed ("Landscape," "Hunting," and "Non-hunting recreation"). Abbreviations: forest ecosystem (F. ecosystem), temperature shift (Temp. shift), non-timber forest products (NTFP)
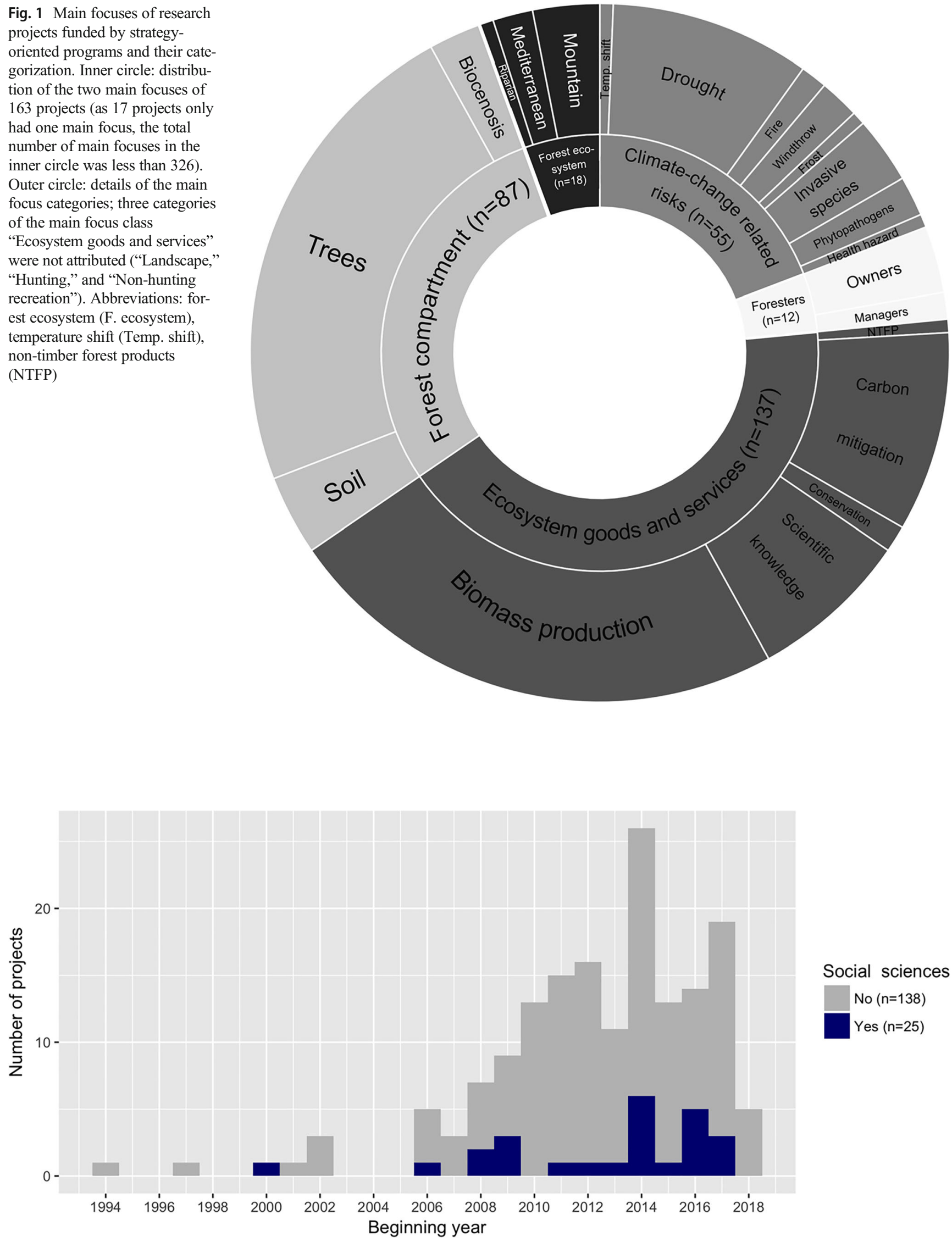

Fig. 2 The inclusion of the social sciences in French projects funded in climate studies in forest research across years 
research. Climate studies carry much uncertainty, and forest research deals with issues related to individual preferences such as esthetic inclination, management intensity choices, or risk aversion. The ambiguity resulting from this intertwining of uncertainty and individual values can prejudice the scientific arguments of a study, as previously reported for the technical preferences of windstorm adaptation in forest management (Fouqueray et al. 2020). Therefore, one way to pursue the best practices in transparent research is to spell out these individual values, so as not to allow scientists' biases to influence their readers. Social scientists are used to employing this approach (Moon and Blackman 2014), and their interaction with forest researchers can help the latter to improve their epistemological position. This holds true for "pure" curiosity-driven climate scientists, but all the more so for researchers dedicated to a problem-solving approach (Crouzat et al. 2018). For these researchers mixing scientific activities with environmental advocacy, clearly stating their scientific position is necessary to maintain their legitimacy as scientists with policy makers and with the general public (Machlis 1992).

Furthermore, the theoretical background of social sciences can enrich experimental sciences (e.g., biology, pedology). As early as 1992, Machlis noted that "Many [sociology] subfields offer help in theory and model development relevant to conservation biology." Swart et al. (2014) highlighted that insights brought by political sciences can help design confirmatory studies using region-based findings.

A final point that should not be neglected in a researcher's life is that the interdisciplinary integration of social sciences leads to higher scientific impact of publications (Larivière et al. 2015; Chen et al. 2015).

Researchers are more than mere passive beneficiaries of the inclusion of social sciences in climate studies in forest research, as they also have the capacity to act in its favor. Experimental scientists who dominate this research landscape have the power to involve social scientists in their funding applications. Conversely, collaborating with social scientists is a good stimulus for experimental scientists to maintain their strong ability to reformulate problems, theories, and research designs related to climate and/or forest issues (Machlis 1992) - which should not be seen as a prerogative of social scientists alone.

\subsubsection{Illustration from the French case study}

The AFFORBALL research project, launched by economists, started in 2016 (Table 1) with the aim to propose "innovative adaptation solutions for the forest-based industry at the territorial scale of the Regional Natural Park, which respond to the global stakes of sustainable development, climate change, biodiversity protection, and economic and environmental resilience of territories" (Caurla and Michel 2016). In order to foster innovation, AFFORBALL researchers agreed on an interdisciplinary mix of sociology, ethnology, economics, and environmental sciences, and on a territorial approach that went beyond the traditional disciplinary limitations. The institutional affiliation of one of AFFORBALL's leaders to INRAE might explain some of the methodological choices, since INRAE is legally mandated to "provide support to public policies that respond to social challenges, especially economic, social, and environmental needs related to sustainable development" (Légifrance 2018).

\subsection{Research funding bodies: "the place to be" for social sciences}

Public funding bodies funnel government funds through calls for proposals. Their specific role at the science-policy interface places them between a rock and a hard place regarding the inclusion of the social sciences. On the one hand, funding bodies are held accountable for the allocation of research budgets, with expectations regarding the scientific impact of the rewarded projects (e.g., Dunningham et al. 2018). Despite their capacity to strengthen the representation of social sciences, this situation leads funding bodies to favor conventional projects with predictable short-term outcomes (Shaman et al. 2013). On the other hand, in the context of global changes, social sciences represent an opportunity to meet the expectations of funding programs for more bottom-up, innovative, and exploratory research, where social sciences have their rightful place in climate studies (Weaver et al. 2014; Wong-Parodi et al. 2016).

We suggest that funding bodies go beyond this paradox by developing guidelines for a better inclusion of social sciences by following the initiative of Schneider et al. (2019) in the field of societal transformation research, which is also valuable for climate studies in forest research.

\subsubsection{Illustration from the French case study}

Despite broad funding priorities that allow for proposals with social sciences, French funding bodies have lagged behind in their stated ambition for greater interdisciplinarity. The example of ADEME, a French agency that funds sustainable development projects, is symbolic. Both interdisciplinarity and social sciences have been spotlighted over the years, as for instance in 2015: "The research priorities of the current call for proposals are [...] projects in economics and social sciences, aiming at favoring and accompanying the agricultural and forest transition (projects specifically in economics and social sciences, or at the interface with other disciplines)" (ADEME 2015). However, none of the 10 forestry projects funded by ADEME in 2013 and 2015 included social or economic analyses (Table 2 in the Annex).

Due to the lack of data about rejected proposals, selection processes, and committees, it is virtually impossible to estimate at which point in the funding allocation process this exclusion of social sciences occurs. Hence, we call on funding bodies to complete the results of funding allocations by also publicizing an 
overview of the rejections (but not the full submissions), subject to the consent of the unsuccessful candidates. This could help confirm our experience that researchers on the selection committees mostly have a background in natural sciences, and might lack the required training in social sciences to adequately grasp the added value of such projects.

Inversely, the lack of data on social sciences for selected projects also concerned the intermediary and final reports of the funded projects. Only 8 out of the 25 websites and reports of projects including social sciences evidenced the use or added value of these disciplines.

\subsection{Role of social sciences at the interface with forest and climate authorities}

For climate change especially, the mutual influence of research projects and policies is well documented, as heralded by the Paris agreement (Falkner 2016). Nevertheless, this mutual influence is unbalanced. On the one hand, researchers and scientific knowledge play a role in framing and designing climate public policies (Aykut 2012), which often remain top-down (Lepori et al. 2007). On the other hand, authorities directly coin the research agendas through public funding (Geuna 2001; Lepori et al. 2007), hoping that the outcomes of climate studies in forest research help meet mitigation and adaptation targets. This is where paying attention to the social sciences in climate or forest-related policies could represent an interesting opportunity for the authorities, as urged in conservation circles (Bennett et al. 2017). Psychology, sociology, and human geography are best at understanding - and thus help overcome - the gap between forest policy objectives and their local implementation by forest managers and owners (Ban et al. 2013; Deuffic 2018).

Sörlin (2013) documented the failure of conventional environmental expertise to grasp the complexity of socialecological systems in the absence of social sciences: social sciences open the door to restore public trust in climate and forest governance and promote more holistic framing of the science-policy interface. Social scientists should therefore take the opportunity to be part of the orientation of climate studies (Shaman et al. 2013).

\subsubsection{Illustration from the French case study}

Informing public policies was an important selection criterion in the calls for proposals. For instance, the public interest group "Forest Ecosystems" (ECOFOR, supported by the French ministries in charge of forests and of the ecological transition) stressed its problem-solving dimension, which aims to inform public policies at national ("The government has decided that biodiversity should be a priority research theme in the coming years"; ECOFOR 2000) and European levels ("a rising synergy between the GICC program and its European homologues through concerted action such as ERA-NET"; ECOFOR 2014).
Because of the importance of the science-policy interface in the calls for proposals, we expected a co-evolution of climate policies and of the focus of climate/forest research over the years, such as a general switch from mitigation-centered research toward projects focusing on risk prevention and ecosystem services. Indeed, initially, all funding bodies and projects effectively focused on mitigation issues but with a decreasing importance over time (Fig. 3 in the Annex).

\subsection{Social sciences: helping foresters to adapt by "not putting all eggs in one basket"}

The uncertainties associated with climate change have resulted in an unusual consensus among foresters, namely the convergence of opinions on the need not to "put all eggs in one basket." An abundant body of literature now outlines the importance of diversifying silvicultural practices and objectives in order to adapt, for instance, through tree species and age diversification (Keenan 2015; Brockerhoff et al. 2017; Augustynczik et al. 2019).

Hence, the social sciences can contribute to foresters' search for diversified adaptation options. Social and economic initiatives in forestry present an interesting yet underestimated potential to diversify adaptation. As an example, ongoing economic research investigates the potential of insurance systems to cope with climate change in forestry (Brèteau-Amores et al. 2019) or assesses the possibility of political measures to alleviate the pressure on timber production (Keenan et al. 2019).

However, to date, social sciences have been neglected compared with technical approaches in climate studies in forest research (Andersson and Keskitalo 2018).

\subsubsection{Illustration from the French case study}

Despite the slightly increasing use of social and economic tools, technical approaches from the environmental sciences (biology, genetics, ecology, etc.) prevail in climate studies in forest research, as illustrated by the strong focus on ecosystem services and the functioning of trees (Fig. 1). Biomass production for timber or fuelwood was the paramount study topic of all the projects analyzed here. Biodiversity was often considered to be part of a project's scope in association with biomass production as a support for productivity reasons. Research issues explored in forest journals between 1979 and 2008 support these findings (Dobbertin and Nobis 2010).

It should be noted, however, that projects funded in the late 2010s pay more attention to the practices of foresters in the field. The studies on how foresters implement adaptation strategies in the field, such as "Observance of adaptation to climate change measures by forest managers" (MACCLIF, Table 1), exemplify this evolution. 


\subsection{Can social sciences bring societal issues back to climate studies and forest research?}

Social sciences represent an opportunity for climate studies in forest research to reconnect with society at large, understood here as all persons without professional or ownership links to forests. At least in Western countries, there seems to be a renewed popular interest in forests due to the popularization of forest science (e.g., Kingsland et al. 2018). However, this interest of "non-foresters" in forest issues is not echoed in climate/forest publications. Social, economic, and policy-related terms are weakly represented in forest journals (Dobbertin and Nobis 2010). For instance, a review of climate studies in forest research in New Zealand stated that in many projects, "There was limited communication with end-users before, during and post research" (Dunningham et al. 2018). Forest stakeholders underestimate the ability of social sciences to elucidate the concerns of society in regard to adaptation issues such as changes in forestry practices. For instance, Klenk et al. (2015) outline how climate change challenges forest certification as stakeholders seek to maintain past ecosystem conditions.

Still, social sciences should not be used as a one-way instrument of foresters to orient society's perception of their forestry practices in a favorable direction. Instead, the inclusion of the social sciences in climate/forest research should contribute to developing a two-way dialogue between foresters and society.

\subsubsection{Illustration from the French case study}

The distribution of the main focuses of the funded research projects illustrates how social sciences are not given full consideration in the funding of French climate studies in forest research. Topics from the experimental sciences are by far overrepresented: main focuses were distributed across "Ecosystem goods and services" $(n=137)$, "Forest compartment" $(n=87)$, "Climate change-related risks" $(n=55)$, "Forest ecosystem" $(n=18)$, and "Foresters" $(n=12)$ (Fig. 1 , Table 1 continued online).

This trend is confirmed by a closer observation of the main focuses: not a single project focused on forest scenery or leisure activities - not even hunting, despite the economic weight of expensive hunting leases (Cinotti 2003) (Fig. 1, Table 1 continued online).

The prevalence of main focuses specific to the experimental sciences (e.g., "Biomass production") responds to the needs of the forestry sector to develop resilient forest management in France, where timber production is an ecosystem service of the utmost economic importance. This also complies with the Lisbon strategy for growth and employment devised by the EU in 2000, which indicates that applied research should aim to support sustainable economic growth (European Commission 2004). With the exception of economics, social sciences are still not viewed as an opportunity to enable progress in climate studies in forest research.

\section{Conclusion}

While interdisciplinarity is of utmost importance for the study of complex social-ecological systems such as managed forests, it should be recalled that disciplinary insights from both the experimental and social sciences are also highly valuable for climate studies (Swart et al. 2014; Fankhauser et al. 2019).

In our view, two main reasons indicate why the time is appropriate for forest researchers to prepare for strengthening interactions with social scientists in climate studies. First, climate studies increasingly tackle adaptation from the angle of "nature-based solutions" or "ecosystem-based adaptation," in which adaptation accounts for "the role of ecosystem services in reducing the vulnerability of society to climate change, in a multi-sectoral and multi-scale approach" (Nesshöver et al. 2017). Ecosystem-based adaptation puts a strong emphasis on social-ecological interactions and favors interdisciplinary research. As it gains in popularity with funders (e.g., in Europe; European Commission 2015), forest researchers will very likely have to increase their connections with social scientists. Second, methodological developments will transform forest research to some extent. The rise of automatic data collection devices, such as LiDAR for forest inventories or drones for the remote monitoring of climate risks, implies an increased use of big data analytics (Zou et al. 2019). Big data analytics proceeds using an exploratory, correlation-based approach in contrast with the causalitybased regime of truth that prevails in forest research. With their tradition of self-exploration, social sciences have the capacity to shed light on the epistemological considerations involved in such a methodological switch (Moon and Blackman 2014). Similar considerations apply to the development of transdisciplinary methodologies in the forest sciences such as the participation of foresters in serious games and participatory simulations (Garcia 2019).

French public funding of climate and forest research clearly illustrates that to date, forest research has been insufficiently geared toward the post-normal vision of science required to face the complexity of the wicked climate change problem. Most projects funded in this research area are a continuation of this trend that ignores the social sciences, while calls for the disciplinary and interdisciplinarity inclusion of the social sciences remain wishful thinking. One reason is the legacy of the technical professional culture of foresters (Boutefeu and 
Arnould 2006), while another is the tendency of education and training programs to leave aside the social aspects of forestry (Marty 2000; Cheikho and Clément 2002; Innes 2005).

Whether change comes from within or not, we argue that climate studies in forest research are in a good position to take social sciences into full consideration and thus provide a good example in comparison with other scientific fields dealing with complex problems. We posit that forest researchers are best placed to promote change across different timescales, as teachers and trainers on the one hand, and as part of research institutions on the other. Our premises should not be seen as specific to the French case study, as they are echoed in other Western countries (Dunningham et al. 2018; Fankhauser et al. 2019).

In the long term, teachers and trainers are best equipped to train students in questioning the perspectives taken in climate studies in forest research (Innes 2005), especially at the critical moment of $\mathrm{PhD}$ research. Recruitment is another crux in the long-term renewal of forest research. We suggest that forest researchers, when reviewing applications for a research and/or teaching position, request for a basic culture in the social sciences to be considered in the selection of candidates in the experimental sciences.

In the medium term, social scientists striving for greater recognition in forest research should have an opportunity to weigh in on long-term funding decisions. We invite them to meet the key challenge of using their scientific visibility to become or stay involved in climate and/or funding bodies. We expect the expansion of interdisciplinary courses in forest training (Hickey and Nitschke 2005; Innes 2005), and hence the change in the education of forest researchers, to bolster the openness of selection committees in this direction in the coming years.

In the short term, as members of editorial boards of forestry journals, researchers have the rare opportunity to diffuse similar propositions to our own in a rapidly changing scientific environment. Despite the implementation difficulties and sometimes a lack of willingness, we believe that the process of including the social sciences more in climate/forest research is ongoing. The publication of this opinion paper in a forest journal is definitely a sign of hope.

Acknowledgments TF is grateful to Annabelle Amm for her valuable insights on the ECOFOR research programs, and to Erwin Dreyer for helpful comments and suggestions.

Funding information This work was supported by a grant from the French National Research Agency (ANR) as part of the "Investments d'Avenir" Programme (LabEx BASC; ANR-11-LABX-0034).

Data availability The datasets generated and/or analyzed during the current study are available in the Zenodo repository, https://doi.org/10.5281/ zenodo. 3946430

\section{Compliance with ethical standards}

Conflict of interest The authors declare that they have no conflict of interest.

\section{Annexes}

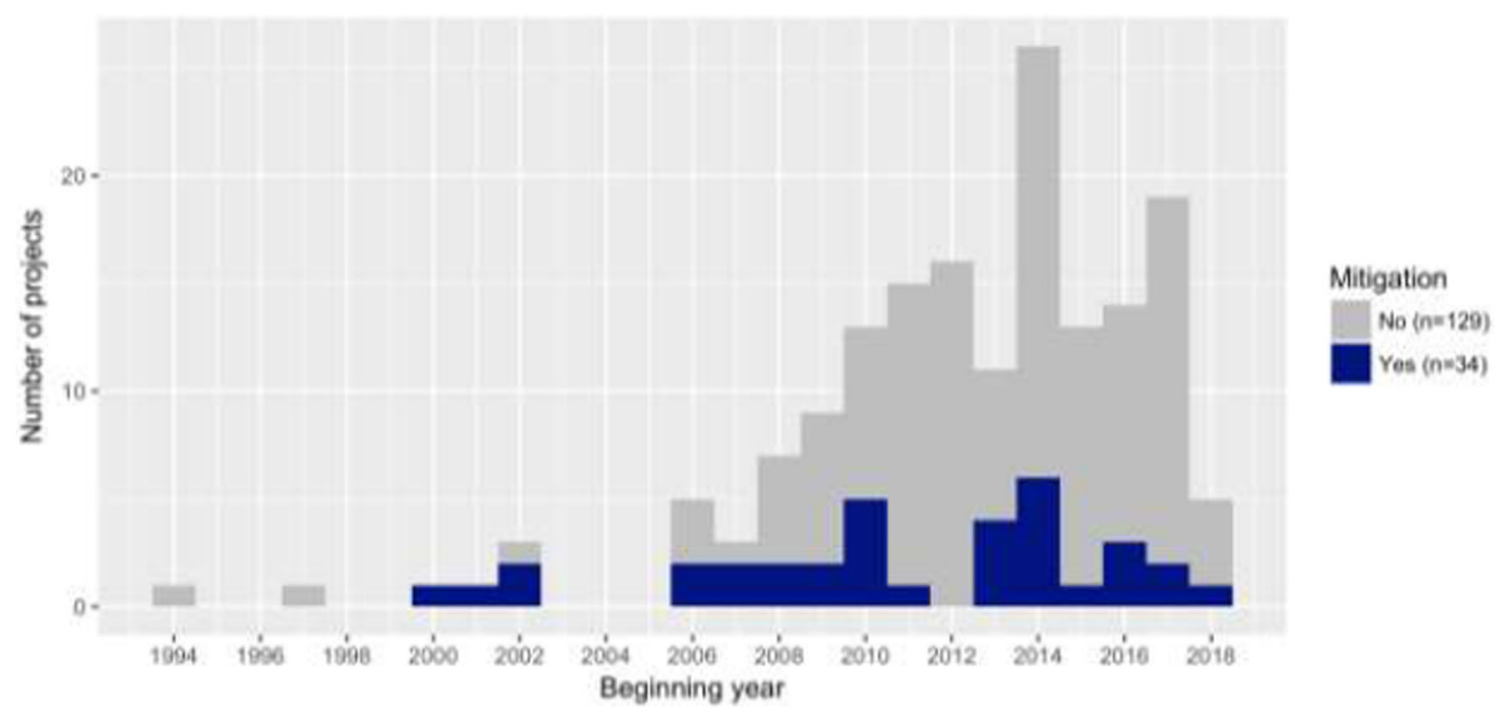

Fig. 3 Evolution of the number of projects explicitly mentioning mitigation in their content description 
Table 2 Research projects funded by the ADEME in 2013 and 2015 for the calls for proposals "Research on mitigation of climate change by agriculture and forest"

\begin{tabular}{clc}
\hline Funding first year & Selected research projects & Reference \\
\hline 2013 & BICAFF & https://appelsaprojets.ademe.fr/aap/ \\
& EEACCTIF2013-2\#resultats \\
& GESFOR & \\
& CESEC & \\
& INSENSE & \\
& PICASO & \\
& RESPIRE & \\
& EVAFORA & \\
& CAPSOL & https://appelsaprojets.ademe.fr/aap/ \\
& SATAN & REACCTIF2015-55-1\#resultats \\
\end{tabular}

\section{References}

ADEME (2015) Appel à projets R\&D REACCTIF 3. Echerche sur l'Atténuation du Changement ClimaTique par l'agrIculture et la Forêt

Aitken SN, Yeaman S, Holliday JA, Wang T, Curtis-McLane S (2008) Adaptation, migration or extirpation: climate change outcomes for tree populations. Evol Appl 1:95-111. https://doi.org/10.1111/j. 1752-4571.2007.00013.x

Andersson E, Keskitalo ECH (2018) Adaptation to climate change? Why business-as-usual remains the logical choice in Swedish forestry. Glob Environ Chang 48:76-85. https://doi.org/10.1016/j. gloenvcha.2017.11.004

Augustynczik ALD, Asbeck T, Basile M, Bauhus J, Storch I, Mikusiński G, Yousefpour R, Hanewinkel M (2019) Diversification of forest management regimes secures tree microhabitats and bird abundance under climate change. Sci Total Environ 650:2717-2730. https:// doi.org/10.1016/j.scitotenv.2018.09.366

Aykut SC (2012) How to govern a "new global risk"? The construction of climate change as a public problem at the global and European levels, in France and Germany. Sciences sociales, Ecole des Hautes Etudes en Sciences Sociales (EHESS)

Ban NC, Mills M, Tam J, Hicks CC, Klain S, Stoeckl N, Bottrill MC, Levine J, Pressey RL, Satterfield T, Chan KMA (2013) A socialecological approach to conservation planning: embedding social considerations. Front Ecol Environ 11:194-202. https://doi.org/10. $1890 / 110205$

Barnes J, Dove MR (2015) Climate cultures: anthropological perspectives on climate change. Yale University Press, New Haven and London

Bennett NJ, Roth R, Klain SC, Chan KMA, Clark DA, Cullman G, Epstein G, Nelson MP, Stedman R, Teel TL, Thomas REW, Wyborn C, Curran D, Greenberg A, Sandlos J, Veríssimo D (2017) Mainstreaming the social sciences in conservation: mainstreaming the social sciences. Conserv Biol 31:56-66. https:// doi.org/10.1111/cobi.12788

Boutefeu B, Arnould P (2006) Le métier de forestier : entre rationalité et sensibilité. Rev For Fr LVIII:12

Brèteau-Amores S, Brunette M, Davi H (2019) An economic comparison of adaptation strategies towards a drought-induced risk of forest decline. Ecol Econ 164:106294. https://doi.org/10.1016/j.ecolecon. 2019.04.006

Brockerhoff EG, Barbaro L, Castagneyrol B, Forrester DI, Gardiner B, González-Olabarria JR, Lyver PO'B, Meurisse N, Oxbrough A, Taki H, Thompson ID, van der Plas F, Jactel H (2017) Forest biodiversity, ecosystem functioning and the provision of ecosystem services. Biodivers Conserv 26:3005-3035. https://doi.org/10. 1007/s10531-017-1453-2

Brunette M, Couture S, Pannequin F (2017) Is forest insurance a relevant vector to induce adaptation efforts to climate change? Ann For Sci 74. https://doi.org/10.1007/s13595-017-0639-9

Bullock R, Lawler J (2015) Community forestry research in Canada: a bibliometric perspective. Forest Policy Econ 59:47-55. https://doi. org/10.1016/j.forpol.2015.05.009

Bussotti F, Pollastrini M, Holland V, Brüggemann W (2015) Functional traits and adaptive capacity of European forests to climate change. Environ Exp Bot 111:91-113. https://doi.org/10.1016/j.envexpbot. 2014.11.006

Caurla S, Michel C (2016) AFFORBALL : Adaptations de la filière forêtbois du PNR des Ballons des Vosges dans un contexte de changements globaux. In: PSDR. https://www.psdr.fr/archives/ INS386PDFN1.pdf. Accessed 31 Mar 2020

Cheikho M, Clément P (2002) Pluridisciplinarité et complexité dans la formation au métier d'ingénieur forestier. ASTER 34. https://doi. org/10.4267/2042/8790

Chen S, Arsenault C, Larivière V (2015) Are top-cited papers more interdisciplinary? J Inf Secur 9:1034-1046. https://doi.org/10.1016/j. joi.2015.09.003

Cinotti B (2003) Une gestion non rentable peut-elle être durable? Rev For Fr 55:7-24

Crouzat E, Arpin I, Brunet L, Colloff MJ, Turkelboom F, Lavorel S (2018) Researchers must be aware of their roles at the interface of ecosystem services science and policy. Ambio 47:97-105. https:// doi.org/10.1007/s13280-017-0939-1

Dessai S, Hulme M, Lempert R, Pielke R (2009) Do we need better predictions to adapt to a changing climate? EOS Trans Am Geophys Union 90:111-112

Deuffic P (2018) Your policy, my rationale. How individual and structural drivers influence European forest owners' decisions. Land Use Policy 79:1024-1038. https://doi.org/10.1016/j.landusepol.2016. 09.021

Diaz S, Settele J, Brondízio ES, et al (2019) Summary for policymakers of the global assessment report on biodiversity and ecosystem services of the Intergovernmental Science-Policy Platform on Biodiversity and Ecosystem Services. IPBES secretariat, Bonn, Germany

Dobbertin MK, Nobis MP (2010) Exploring research issues in selected forest journals 1979-2008. Ann For Sci 67:800-800. https://doi.org/ 10.1051 /forest $/ 2010052$

Dunningham A, Grant A, Wreford A (2018) A review of climate change research in New Zealand focusing on forestry. MPI Tech Pap 93

ECOFOR (2000) Programme Biodiversité et Gestion Forestière - Appel à propositions de recherche 2000 
ECOFOR (2014) Programme Gestion et Impacts du Changement Climatique - APR 2014

Edenhofer O, IPCC (eds) (2014) Climate change 2014: mitigation of climate change ; Working Group III contribution to the Fifth Assessment Report of the Intergovernmental Panel on Climate Change. Cambridge Univ. Press, New York

European Commission (ed) (2004) Facing the challenge: the Lisbon strategy for growth and employment: report from the High Level Group chaired by Wim Kok. Office for Official Publications of the European Communities, Luxembourg

European Commission (2015) Towards an EU research and innovation policy agenda for nature-based solutions \& re-naturing cities: final report of the Horizon 2020 expert group on 'Nature-based solutions and re-naturing cities': (full version). Publications Office of the European Union, Luxembourg

Falkner R (2016) The Paris Agreement and the new logic of international climate politics. Int Aff 92:1107-1125. https://doi.org/10.1111/ 1468-2346.12708

Fankhauser S, de Menezes A, Opacic N (2019) UK research on the social science of climate change - a synthesis of ESRC and related investments. Place-Based Clim Action Netw Lond Sch Econ Polit Sci 46

Fouqueray T (2020) French research projects funded on climate studies and forest research between 1997 and 2017 [Data set]. Zenodo V1. https://doi.org/10.5281/zenodo.3946430

Fouqueray T, Charpentier A, Trommetter M, Frascaria-Lacoste N (2020) The calm before the storm: how climate change drives forestry evolutions. For Ecol Manag 460:117880. https://doi.org/10.1016/j. foreco.2020.117880

Funtowicz SO, Ravetz JR (1994) Uncertainty, complexity and postnormal science. Environ Toxicol Chem 13:1881-1885. https://doi. org/10.1002/etc.5620131203

Garcia C (2019) Could play be a game-changer for the world's forests? In: World Econ. Forum. https://www.weforum.org/agenda/2019/05/ could-games-solve-the-worlds-deforestation-crisis/. Accessed 15 May 2019

García CE, Sanz-Menéndez L (2005) Competition for funding as an indicator of research competitiveness. Scientometrics 64:271-300

Geuna A (2001) The changing rationale for European university research funding: are there negative unintended consequences? J Econ Issues 35:607-632. https://doi.org/10.1080/00213624.2001.11506393

Haunschild R, Bornmann L, Marx W (2016) Climate change research in view of bibliometrics. PLoS One 11:e0160393. https://doi.org/10. 1371/journal.pone. 0160393

Hickey GM, Nitschke CR (2005) Crossing disciplinary boundaries in forest research: an international challenge. For Chron 81:321-323. https://doi.org/10.5558/tfc81321-3

Innes JL (2005) Multidisciplinarity, interdisciplinarity and training in forestry and forest research. For Chron 81:324-329. https://doi. org/10.5558/tfc $81324-3$

Jacobs B, Nelson R, Kuruppu N, Leith P (2015) An adaptive capacity guide book: assessing, building and evaluating the capacity of communities to adapt in a changing climate. South Slopes Clim Change Adapt Res Partnersh SCARP Univ Technol Syd Univ Tasman Hobart Tasman ISBN 9781862958272

Keenan RJ (2015) Climate change impacts and adaptation in forest management: a review. Ann For Sci 72:145-167. https://doi.org/10. 1007/s13595-014-0446-5

Keenan RJ, Nelson H, Keskitalo ECH, Bergh J (2019) Climate change adaptation in forest production systems in a globalizing economy. Res Handb Clim Change Adapt Policy

Kingsland SE, Wohlleben P, Billinghurst J, Flannery T (2018) Facts or fairy tales? Peter Wohlleben and the hidden life of trees. Bull Ecol Soc Am 99:1-5

Klenk NL, Dabros A, Hickey GM (2010) Quantifying the research impact of the Sustainable Forest Management Network in the social sciences: a bibliometric study. Can J For Res 40:2248-2255. https:// doi.org/10.1139/X10-138

Klenk NL, Larson BMH, McDermott CL (2015) Adapting forest certification to climate change. Wiley Interdiscip Rev Clim Chang 6:189201. https://doi.org/10.1002/wcc.329

Larivière V, Haustein S, Börner K (2015) Long-distance interdisciplinarity leads to higher scientific impact. PLoS One 10:e0122565. https:// doi.org/10.1371/journal.pone.0122565

Légifrance (2018) Legifrance, le service public de la diffusion du droit. In: Serv. Public Diffus. Droit. https://www.legifrance.gouv.fr/. Accessed 16 Jul 2018

Lepori B, Reale E (2019) The changing governance of research systems. Agencification and organizational differentiation in research funding organizations. In: Handbook on science and public policy. Edward Elgar, pp 448-465

Lepori B, Van den Besselaar P, Dinges M et al (2007) Comparing the evolution of national research policies: what patterns of change? Sci Public Policy 34:372-388

Lindner M, Maroschek M, Netherer S, Kremer A, Barbati A, GarciaGonzalo J, Seidl R, Delzon S, Corona P, Kolström M, Lexer MJ, Marchetti M (2010) Climate change impacts, adaptive capacity, and vulnerability of European forest ecosystems. For Ecol Manag 259: 698-709. https://doi.org/10.1016/j.foreco.2009.09.023

Luthe T, Wyss R (2015) Introducing adaptive waves as a concept to inform mental models of resilience. Sustain Sci 10:673-685. https://doi.org/10.1007/s11625-015-0316-6

MAAF (2017) Programme National de la Forêt et du Bois 2016-2026. Ministère de l'Agriculture, de l'Agroalimentaire et de la Forêt, Paris

Machlis GE (1992) The contribution of sociology to biodiversity research and management. Biol Conserv 62:161-170. https://doi.org/10. 1016/0006-3207(92)91044-S

Marchi E, Chung W, Visser R, Abbas D, Nordfjell T, Mederski PS, McEwan A, Brink M, Laschi A (2018) Sustainable Forest Operations (SFO): a new paradigm in a changing world and climate. Sci Total Environ 634:1385-1397. https://doi.org/10.1016/j. scitotenv.2018.04.084

Marcin TC (1995) Integrating social sciences into forest ecosystem management research. J For 93:29-33

Marty P (2000) Pourquoi étudier la vulgarisation des sciences forestières ? Etude des formations à la gestion des forêts. Nat Sci Soc 8:63-65. https://doi.org/10.1016/S1240-1307(00)88797-X

Meyer M, Molyneux-Hodgson S (2010) Introduction: the dynamics of epistemic communities. Sociol Res Online 15:1-7. https://doi.org/ $10.5153 /$ sro. 2154

Ministère de l'écologie, du Développement durable et de l'énergie (2012) Stratégie nationale pour la biodiversité 2011-2020. https://www. ecologique-solidaire.gouv.fr/strategie-nationale-biodiversite Accessed 01/10/2016

Moon K, Blackman D (2014) A guide to understanding social science research for natural scientists: social science for natural scientists. Conserv Biol 28:1167-1177. https://doi.org/10.1111/cobi.12326

MTES (2018) Stratégie Nationale de Mobilisation de la Biomasse. Ministère de la Transition Écologique et Solidaire, France. https:// www.ecologique-solidaire.gouv.fr/sites/default/files/Stratgie/ Nationale/de/Mobilisation/de/la/Biomasse.pdf. Accessed 15/07/ 2019

MTES (2020) Stratégie Nationale Bas Carbone. Ministère de la Transition Écologique et Solidaire, France. https://www. ecologique-solidaire.gouv.fr/sites/default/files/2020-03-25_MTES_ SNBC2.pdf. Accessed 15/07/2020

Nelson HW, Williamson TB, Macaulay C, Mahony C (2016) Assessing the potential for forest management practitioner participation in climate change adaptation. For Ecol Manag 360:388-399. https://doi. org/10.1016/j.foreco.2015.09.038

Nesshöver C, Assmuth T, Irvine KN, Rusch GM, Waylen KA, Delbaere B, Haase D, Jones-Walters L, Keune H, Kovacs E, Krauze K, 
Külvik M, Rey F, van Dijk J, Vistad OI, Wilkinson ME, Wittmer H (2017) The science, policy and practice of nature-based solutions: an interdisciplinary perspective. Sci Total Environ 579:1215-1227. https://doi.org/10.1016/j.scitotenv.2016.11.106

ONERC (2017) Recommandations pour un nouveau Plan national d'adaptation au changement climatique. Observatoire National des Effets du Réchauffement Climatique, Paris

Schneider F, Buser T, Keller R, Tribaldos T, Rist S (2019) Research funding programmes aiming for societal transformations: ten key stages. Sci Public Policy 46:463-478. https://doi.org/10.1093/ scipol/scy074

Shaman J, Solomon S, Colwell RR, Field CB (2013) Fostering advances in interdisciplinary climate science. Proc Natl Acad Sci 110:36533656. https://doi.org/10.1073/pnas. 1301104110

Sörlin S (2013) Reconfiguring environmental expertise. Environ Sci Pol 28:14-24. https://doi.org/10.1016/j.envsci.2012.11.006

Spittlehouse DL, Stewart RB (2004) Adaptation to climate change in forest management. J Ecosyst Manag 4

Sun J, Yang K (2016) The wicked problem of climate change: a new approach based on social mess and fragmentation. Sustainability 8: 1312. https://doi.org/10.3390/su8121312
Swart R, Biesbroek R, Lourenço TC (2014) Science of adaptation to climate change and science for adaptation. Front Environ Sci 2. https://doi.org/10.3389/fenvs.2014.00029

Weaver CP, Mooney S, Allen D, Beller-Simms N, Fish T, Grambsch AE, Hohenstein W, Jacobs K, Kenney MA, Lane MA, Langner L, Larson E, McGinnis DL, Moss RH, Nichols LG, Nierenberg C, Seyller EA, Stern PC, Winthrop R (2014) From global change science to action with social sciences. Nat Clim Chang 4:656-659. https://doi.org/10.1038/nclimate2319

Wong-Parodi G, Krishnamurti T, Davis A, Schwartz D, Fischhoff B (2016) A decision science approach for integrating social science in climate and energy solutions. Nat Clim Chang 6:563-569. https:// doi.org/10.1038/nclimate2917

Zou W, Jing W, Chen G, Lu Y, Song H (2019) A survey of big data analytics for smart forestry. IEEE Access 7:46621-46636. https:// doi.org/10.1109/ACCESS.2019.2907999

Publisher's note Springer Nature remains neutral with regard to jurisdictional claims in published maps and institutional affiliations. 